Review Paper:

\title{
Effect of Body Position on Physiological Alteration While crosshark Feeding Infants: A Systematic Review
}

\author{
Nazanin Azimi Jahed ${ }^{1}$, Leili Borimnejad ${ }^{2 *}$, Hamid Haghani ${ }^{3}$ \\ 1. Department of Neonatal Intensive Care Nursing, School of Nursing and Midwifery, Iran University of Medical Sciences, Tehran, Iran \\ 2. Nursing Care Research Center, Iran University of Medical Sciences, Tehran, Iran. \\ 3. Department of Biostatistics, School of Public Health, Iran University of Medical Sciences, Tehran, Iran
}

\begin{tabular}{|c|c|}
\hline & Ctation: Azimi Jahed, N., Borimnejad, L. \& Haghani, H., 2017. Effect of Body Position on Physiological Alteration While Feed- \\
\hline 口Fitita & ing Infants: A Systematic Review. Journal of Client-Centered Nursing Care, 3(2), pp. 119-124. https://doi.org/10.32598/jccnc.3.2.119 \\
\hline 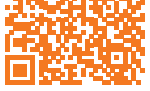 & dol : https://doi.org/10.32598/jccnc.3.2.119 \\
\hline
\end{tabular}

Article info:

Received: 23 Oct. 2016

Accepted: 10 Feb. 2017

Keywords:

Posture, Infant, Heart rate, Oxygen saturation, Feeding

\begin{abstract}
A B S T R A C T
Background: An infant should be able to coordinate sucking, swallowing, and breathing to have a safe and effective feeding, which is developed with the increasing gestational age. Any problem in each of these functions can lead to the risk of aspiration, pneumonia, decreased oxygenation saturation, apnea, and bradycardia. The changed body positions may cause changes in the physiological efficiencies of the preterm infants. The objective of this review is to determine the impact of body position on the physiological alternations in the preterm infants while bottle feeding.

Methods: In order to review the previous studies, we referred the related resources from existing databases such as Scopus, Ovid, Science Direct, ProQuest, Pub Med, Wiley Cochrane Library, Magiran, Medlib, SID, and Google Scholar. Both English (from 1997 to 2016) and Persian studies (from 2010 to 2016) were reviewed.

Results: Four clinical trials with eligible criteria were used as a crossover while the infants were bottle fed. The body positions that are considered in this study include elevated side-lying position vs. semi-upright position, upright position vs. cradle position, side-lying position vs. cradle position, and semi-elevated supine position vs. semi-elevated side-lying position to determine the effect of the physiological parameters while bottle feeding the premature infants.

Conclusion: It seems that there is still not enough evidence to determine the positions affecting the physiological parameters of an infant while bottle feeding. Thus, it seems necessary to have further studies to analyze the impact of proper body position on the infant's physiological alternations.
\end{abstract}

\section{Background}

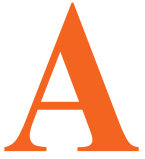

ccording to $\mathrm{WHO}$, one in every ten infants are born prematurely all over the world with a gradual increase in the number nowadays (World Health Organiza- tion 2012; World Health Organization 2014). Of all, low birth weight infants are at greater risk. It is, therefore, necessary to pay more attention to their feeding position to monitor their growth in a better way (World Health Organization 2016).

\section{* Corresponding Author:}

Leili Borimnejad, PhD

Address: Nursing Care Research Center, Iran University of Medical Sciences, Tehran, Iran

Tel: +98 (912) 5029548

E-mail: l.borimnejad@gmail.com 
Generally, an infant should be able to coordinate sucking, swallowing, and breathing to have a safe and effective feeding, which is developed with the increasing gestational age. Any problem in each of these functions can lead to the risk of aspiration, pneumonia, decreased oxygenation saturation, apnea, and bradycardia (Sabrina Lopes et al. 2014; Clark et al. 2007). Coordination of sucking and swallowing occurs when the infant shows no symptoms of aspiration, decreased oxygenation saturation, apnea, or bradycardia in the proportion of $1: 1: 1$ or 2:2:1 for sucking: swallowing: breathing, respectively (Barlow 2009). According to Gewolb and Vice, there are 9 patterns of breathing and swallowing. The pattern 5 (apnea-swallow-apnea) is a dominant pattern for premature infants of 32-34 weeks post-menstrual age, which changes to pattern 7 (inhale-swallow-exhale) after maturation (Park 2012).

A termed infant is capable of sucking and breathing simultaneously. While sucking, breathing is interrupted for a short while oxygen saturation $\left(\mathrm{SpO}_{2}\right)$ is still high. But, it is less in bottle feeding compared to breast feeding because milk comes in variable flow from breast and compressibility is less (Sakalidis et al. 2012). Feeding problems of preterm infants have been reported in lots of studies including those with increased physiological instability, weak sucking pattern, low coordination between sucking and swallowing, insufficient absorption, and increased duration to complete the oral intake (Park et al. 2014).

Nutritional support, which includes even the tracing of the minimum drop in oxygen during feeding, is one of the major aspects of care for those who take care of the preterm infants. It is also believed that sufficient oxygenation helps in maintaining the body tune; oral move control; coordination of sucking, swallowing, and breathing during feeding. Infants with more oxygen drop during their feeding, make a less effort for sucking as a result of which it takes a long time to attain the complete oral feeding (Thoyre \& Carlson 2003a). In response to the increased impact of breathing, cardiac output of supplying blood, oxygen, and adequate food increases during feeding. In the heart of a mature person, cardiac contractility increases to enhance cardiac output, but in the preterm heart it causes more impulses. Therefore, the heart rate can be a good indication of physiological function to maintain an infant's stability (Park 2012).

Following the improvements in the care of infants, it resulted in the promotion of the survival of premature infants with more attention towards the importance of feeding strategies (Clark et al. 2007). Positioning is a simple strategy that is applicable while taking care of the infants. There are no definite guidelines for health care providers, according to the prior clinical evidences, about the infant's position during feeding (Park 2012). There is, therefore, a review of the impact of positioning during bottle feeding infants over their physiological stability in order to determine a better position in feeding infants to help in their growth in a non-invasive manner.

\section{Materials and Methods}

All published articles based on randomized and quasirandomized clinical trial, and also crossover studies with proper conditions were included in this study through an electronic search. Databases such as Scopus, Ovid, Science Direct, ProQuest, Pub Med, Wiley Cochrane Library, Magiran, Medlib, SID, and Google Scholar were referred. English keywords, i.e., position nutrition newborn from 1997 to 2016, and Persian keywords including Vaz'iyat-e qarar-giri (position) Taqzia (nutrition) Nowzad (newborn) from 2010 to 2016 were searched. At the first step, each article was scanned and then selected for analysis after meeting all the required criteria. The quality of previous studies was decided by using the Cochran bias search tool.

\section{Results}

Total 4 clinical trials with crossover eligible criteria were selected to study the impact of the positioning of preterm infants while bottle feeding $(\mathrm{N}=57$ ) (Clark et al, 2007) $(\mathrm{N}=6)$; Stevens (2007) $(\mathrm{N}=20)$; Dawson et al. (2013) $(\mathrm{N}=25)$; and Park et al. (2014) $(\mathrm{N}=6)$. There was no Persian study in this concern. All four crossover studies reviewed the impact of different positions on physiological parameters during bottle feeding, as mentioned in Table 1.

Clark et al. (2007) in their review of elevated sidelying vs. semi-upright showed that there is no significant statistical difference between two positions, but the heart rate increased in the first 3 minutes of feeding and returned to the normal state in the mid 3 minutes, and thus, the elevated side-lying position was more preferred. There was a significant interaction between nutrition and feeding positions, with the decreased rate of $\mathrm{SpO}_{2}$ during the first 3 minutes of feeding in both the positions, which later increased to mid 3 minutes in the elevated side-lying position while decreased in the semiupright position.

Stevens (2007) indicated there is no significant difference in feeding in an upright position (head and body in 
Table 1. List of the studies conducted on the effect of body position on physiological stability of infants during feeding

\begin{tabular}{|c|c|c|c|c|c|c|}
\hline No. & Study Title & Author & Study Type & $\begin{array}{l}\text { Study } \\
\text { Place }\end{array}$ & Sample Size & Intervention \\
\hline 1 & $\begin{array}{l}\text { Improving } \\
\text { bottle feeding in } \\
\text { preterm infants: } \\
\text { Investigating the } \\
\text { elevated side- } \\
\text { lying position }\end{array}$ & $\begin{array}{c}\text { Clark et al. } \\
\text { (2007) }\end{array}$ & A pilot study & $\begin{array}{l}\text { Neonatal } \\
\text { unit at } \\
\text { the Royal } \\
\text { London } \\
\text { Hospital }\end{array}$ & $\begin{array}{c}\text { Six infants } \\
\text { were in- } \\
\text { cluded who } \\
\text { were born at } \\
\text { less than or } \\
\text { at } 29 \text { weeks } \\
\text { gestational } \\
\text { age. }\end{array}$ & $\begin{array}{l}\text { Each infant was fed } \\
\text { in both semi-up- } \\
\text { right and Elevated } \\
\text { Side-Lying (ESL) } \\
\text { positions. } \\
\text { Oxygen saturation } \\
\text { and heart rate } \\
\text { were analyzed } \\
\text { before feeding and } \\
\text { for the first } 3 \text { min- } \\
\text { utes in the begin- } \\
\text { ning and followed } \\
\text { by } 3 \text { more minutes } \\
\text { at mid-point of } \\
\text { each feed. }\end{array}$ \\
\hline
\end{tabular}

In all six study infants, $\mathrm{SpO}_{2}$ decreased during the first $3 \mathrm{~min}$ of bottle feeds, regardless of position. However, during the following 3 min, $\mathrm{SpO}_{2}$ continued to decline in the semiupright position but rose in the side-lying position.

No significant effects of variation in heart rate were found in this analysis. The variation in heart rate increased during the first 3 minutes of feeds, and then returned to close proximity to the baseline level in the middle

3 minutes. This trend towards baseline levels was more marked with the ESL feeds.

\begin{tabular}{|c|c|c|c|c|c|c|c|}
\hline 2 & $\begin{array}{l}\text { Preterm infant } \\
\text { feeding and } \\
\text { cardiorespira- } \\
\text { tory stability }\end{array}$ & $\begin{array}{l}\text { Stevens } \\
(2007)\end{array}$ & $\begin{array}{l}\text { A ran- } \\
\text { domized, } \\
\text { two-period, } \\
\text { cross-over } \\
\text { design }\end{array}$ & $\begin{array}{l}\text { Level } 3 \\
\text { NICU at the } \\
\text { Magee- } \\
\text { Women } \\
\text { Hospital } \\
\text { of the Uni- } \\
\text { versity of } \\
\text { Pittsburgh }\end{array}$ & $\begin{array}{l}20 \text { Preterm } \\
\text { infant within } \\
32 \text { to } 40 \text { ges- } \\
\text { tational age }\end{array}$ & $\begin{array}{l}\text { Upright ( } 45 \text { degree } \\
\text { head up) and } \\
\text { Cradle ( } 15 \text { degree } \\
\text { head up) feed- } \\
\text { ing positions on } \\
\text { cardiorespiratory } \\
\text { stability }\end{array}$ & $\begin{array}{l}\text { Findings indicated that } \\
\text { neither the Cradle nor } \\
\text { the Upright feeding } \\
\text { positions had a statisti- } \\
\text { cally significant effect } \\
\text { on the preterm infant's } \\
\text { cardiorespiratory } \\
\text { stability. }\end{array}$ \\
\hline 3 & $\begin{array}{l}\text { A randomized } \\
\text { trial of two tech- } \\
\text { niques for bottle } \\
\text { feeding preterm } \\
\text { infants }\end{array}$ & $\begin{array}{l}\text { Dawson et } \\
\text { al. (2013) }\end{array}$ & $\begin{array}{l}\text { Randomized } \\
\text { pilot study } \\
\text { of cross- } \\
\text { over trial }\end{array}$ & $\begin{array}{l}\text { Newborn } \\
\text { Intensive } \\
\text { and Special } \\
\text { Care unit at } \\
\text { The Royal } \\
\text { Women's } \\
\text { Hospital, } \\
\text { Melbourne, } \\
\text { Australia }\end{array}$ & $\begin{array}{l}25 \text { Infants } \\
\text { including } \\
\text { those who } \\
\text { were at <34 } \\
\text { weeks' gesta- } \\
\text { tion age and } \\
34 \text { weeks' } \\
\text { postmen- } \\
\text { strual age at } \\
\text { the time of } \\
\text { the study }\end{array}$ & $\begin{array}{l}\text { Each infant } \\
\text { received two study } \\
\text { feeds. One feed } \\
\text { was given in the } \\
\text { cradle-hold posi- } \\
\text { tion and the other } \\
\text { in the side-lying } \\
\text { position. } \\
\text { The order of the } \\
\text { first feed was ran- } \\
\text { domized with the } \\
\text { second feed that } \\
\text { was given within } \\
\text { the next } 24 \text { h in an } \\
\text { alternate position. } \\
\text { SpO and Heart } \\
\text { Rate (HR) before, } \\
\text { during, and after } \\
30 \text { mins of feeds. } \\
\text { The respiratory } \\
\text { rate was recorded } \\
\text { before the feed, } \\
\text { every } 5 \text { min during } \\
\text { the feed, and every } \\
10 \text { min after the } \\
\text { feed was com- } \\
\text { pleted }\end{array}$ & $\begin{array}{l}\text { There was no clinically } \\
\text { significant physiologi- } \\
\text { cal instability in } \mathrm{SpO}_{2^{\prime}} \\
\text { respiratory rate, or in } \\
\text { the frequency of brady- } \\
\text { cardia between the two } \\
\text { feeding positions. }\end{array}$ \\
\hline
\end{tabular}




\begin{tabular}{lllllll}
\hline No. Study Title $\quad$ Author & Study Type & $\begin{array}{l}\text { Study } \\
\text { Place }\end{array}$ Sample Size & Intervention & Results \\
\hline
\end{tabular}

\begin{tabular}{|c|c|c|c|c|c|c|c|}
\hline 4 & $\begin{array}{c}\text { Efficacy of } \\
\text { semi-elevated } \\
\text { side-lying posi- } \\
\text { tioning during } \\
\text { bottle-feeding } \\
\text { of very preterm } \\
\text { infants }\end{array}$ & $\begin{array}{c}\text { Park et al. } \\
\text { (2014) }\end{array}$ & $\begin{array}{l}\text { Cross-over } \\
\text { design pilot } \\
\text { study }\end{array}$ & $\begin{array}{l}\text { Level III } \\
\text { Neonatal } \\
\text { Intensive } \\
\text { Care Unit } \\
\text { in North } \\
\text { Carolina }\end{array}$ & $\begin{array}{l}6 \text { Very pre- } \\
\text { term infants } \\
(\leq 30 \text { week } \\
\text { gestational } \\
\text { age })\end{array}$ & $\begin{array}{c}\text { Each infant was } \\
\text { bottle-fed twice } \\
\text { within a 9-hour } \\
\text { period of time on a } \\
\text { single day in both } \\
\text { the semi-elevated } \\
\text { side-lying (ESL) } \\
\text { and semi-elevated } \\
\text { supine (ESU) posi- } \\
\text { tions. } \\
\text { Physiological } \\
\text { stability (heart } \\
\text { rate, SpO, and } \\
\text { respiratory char- } \\
\text { acteristics) and } \\
\text { feeding perfor- } \\
\text { mance (percent } \\
\text { intake, proficiency, } \\
\text { efficiency, and du- } \\
\text { ration of feeding) } \\
\text { were measured } \\
\text { before and/or dur- } \\
\text { ing feeding, when } \\
\text { the infant was calm } \\
\text { and quiet. }\end{array}$ & $\begin{array}{l}\text { Very preterm infants } \\
\text { fed in the ESL position } \\
\text { demonstrated signifi- } \\
\text { cantly less variation in } \\
\text { heart rate, less severe } \\
\text { and fewer decreases in } \\
\text { heart rate, respiratory } \\
\text { rate that was closer to } \\
\text { the pre-feeding state, } \\
\text { shorter and more regu- } \\
\text { lar intervals between } \\
\text { breaths, and briefer } \\
\text { feeding-related apneic } \\
\text { events. No significant } \\
\text { differences for } \mathrm{SpO}_{2} \text { or } \\
\text { feeding performance } \\
\text { were found. }\end{array}$ \\
\hline
\end{tabular}

Client-Centered Nursing Care

$45^{\circ}$ ) vs. cradle position (head and body in $15^{\circ}$ ). However, the results showed that heart rate was slightly lower, and $\mathrm{SpO}_{2}$ and the feeding time were shorter in semi-upright position vs. cradle position.

Dawson et al. (2013) tried feeding each infant twice in 24 hours gaps in both side-lying and cradle positions; and measured their heart rate, $\mathrm{SpO}_{2}$, and respiratory rate prior to, during, and after 30 minutes of being fed. There was a small difference in oxygen saturation between the cradle position (94\%) and side-lying (95\%). The drop in oxygen saturation was recorded in $68 \%$ of infants in the cradle position, and $56 \%$ in the side-lying position. There was a very small difference in the heart rate prior to, during, and 30 minutes of being fed between two positions, whereas the infants fed in cradle position experienced a less number of symptomatic bradycardia (100 beat/min). There was no significant difference between two positions for respiratory rate. The resulted time to complete feeding was found to be 27 minutes for cradle position, and 23 minutes for side-lying. It was also found that the milk consumed in cradle position was comparatively less.

Park et al. (2014) tried feeding each infant twice in 9 hours gaps in both semi-elevated side-lying and semielevated supine positions; and measured their heart rate,
$\mathrm{SpO}_{2}$, and respiratory rate prior to and during being fed. There was a small difference in oxygen saturation for cradle position (94\%) and side-lying (95\%), whereas the drop in the oxygen saturation was recorded in $68 \%$ of infants in the cradle position, and 56\% in the side-lying position. There was a very small difference in heart rate prior to, during, and after 30 minutes of being fed between two positions. The infants fed in cradle position experienced a less number of symptomatic bradycardia (100 beat/min). There was no significant difference between two positions for respiratory rate.

\section{Discussion}

These two cases, among all the selected studies, tended to obtain a better stability in side-lying during feeding (Clark et al. 2007; Park et al. 2014); where two other studied deduced that there is no significant difference between two positions (Stevens 2007; Dawson et al. 2013). It was further observed in two studies that milk consuming was more when the infants were in side-lying position, but their head angles were different in these cases (Dawson et al. 2013; Park et al. 2014). It was also shown that semi-elevated supine position was more efficient and needed less skill compared to the side-lying position (Park et al. 2014). In a systematic review studied by Gillies, Wells, and Bhandari (2012), there was no sig- 
nificant difference in arterial oxygen saturation for both side-lying and supine positions. They also observed that the direction of infant's placement, either in right or left, had no impact on the physiologic stability of the infants.

Findings of this study are in accordance with the results obtained by Balaguer et al., (2013). They reviewed seven studies, which were conducted on the impact of the infants' positioning on physiological stability under mechanical ventilation, and found that there was no significant difference. They suggested about the prone position, whose effects on infants' physiological parameters during feeding are not yet studied. However, this position is also suggested by Kallet (2015) to facilitate infants' tolerance of enteral nutrition. Raiten et al., (2016) evaluated the evidence for feeding premature infants and indicated that none of these evidences suffice for preparing of the infants' clinical guidelines.

Regarding the quality of the studies, it can be said that there is not enough evidence for the importance of the role of preterm infants' positioning on their physiological parameters while being fed. In all cases, the infants were placed in a selected position for a short period of time resulting in the inappropriate blinding and randomization of the small sample size. The lack of considering the long-term effects of positioning is also another constrain for such a study. It is evident that there is not enough evidence and sample to define the role of an infant's positioning on its physiological stability while feeding. It is, therefore, necessary to study such impacts and the related angle more deeply by implementing better methodologies in future studies.

\section{Acknowledgments}

This paper is based on the MSc. thesis of the first Author in the Department of Neonatal Intensive Care Nursing, School of Nursing and Midwifery, Iran University of Medical Sciences of Tehran. The Authors are thankful to International Campus of Iran University of Medical Sciences, Nursing and Midwifery School for financial support. This work has registered by IR.IUMS.REC.1394.9213387201 in Iran Center for Clinical Trials.

\section{Conflict of Interest}

The authors declared no conflicts of interest.

\section{References}

Abdeyazdan, Z., et al., 2015. [Investigation of oxygenation in premature infants under mechanical ventilation in supine position compare to side lying (Persian)]. Journal of Holistic Nursing and Midwifery, 25(1), pp. 18-25.

Balaguer, A., et al., 2013. Infant position in neonates receiving mechanical ventilation A. Cochrane Database of Systematic Reviews, 11. doi: 10.1002/14651858.cd003668.pub3

Barlow, S. M., 2009. Oral and respiratory control for preterm feeding. Current Opinion in Otolaryngology \& Head and Neck Surgery, 17(3), pp. 179-86. doi: 10.1097/moo.0b013e32832b36fe

Chan, S. H. T., et al., 2016. Nutrition and neurodevelopmental outcomes in preterm infants: A systematic review. Acta Paediatrica, 105(6), pp. 587-99. doi: 10.1111/apa.13344

Clark, L., et al., 2007. Improving bottle feeding in preterm infants: Investigating the elevated side lying position. Infant, 3(4), pp. 154-158.

Dawson, J. A., et al., 2013. A randomised trial of two techniques for bottle feeding preterm infants. Journal of Paediatrics and Child Health, 49(6), pp. 462-6. doi: 10.1111/jpc.12208

Elser, H. E., 2012. Positioning after feedings. Advances in Neonatal Care, 12(3), pp. 172-5. doi: 10.1097/anc.0b013e318256b7c1

Gillies, D., Wells, D. \& Bhandari, A. P., 2012. Positioning for acute respiratory distress in hospitalised infants and children. Cochrane Database of Systematic Reviews. doi: 10.1002/14651858. cd003645.pub3

Gouna, G., et al., 2013. Positioning effects on lung function and breathing pattern in premature newborns. The Journal of Pediatrics, 162(6), pp. 1133-7.e1. doi: 10.1016/j.jpeds.2012.11.036

Kallet, R. H., 2015. A comprehensive review of prone position in ARDS. Respiratory Care, 60(11), pp. 1660-87. doi: 10.4187/ respcare.04271

Park, J., 2012. Feeding outcomes in very preterm infants: Preliminary effects of positioning (PhD dissertation). Chapel Hill, North Carolina: The University of North Carolina at Chapel Hill.

Park, J. et al., 2014. Efficacy of semielevated side lying positioning during bottle feeding of very preterm infants. The Journal of Perinatal E Neonatal Nursing, 28(1), pp. 69-79. doi: 10.1097/ jpn.0000000000000004

Picheansathian, W., Woragidpoonpol, P. \& Baosoung, C., 2009. Positioning of preterm infants for optimal physiological development: A systematic review. JBI Database of Systematic Reviews and Implementation Reports, 7(7), pp. 224-59. doi: 10.11124/01938924-200907070-00001

Raiten, D. J., et al., 2016. Working group reports: Evaluation of the evidence to support practice guidelines for nutritional care of preterm infants - the Pre-B Project. The American Journal of Clinical Nutrition, 103(2), pp. 648S-78S. doi: 10.3945/ajcn.115.117309

Sabrina Lopes, L., et al., 2014. A non invasive technique for evaluation of respiratory efforts in preterm infants during feeding. Journal of Neonatal Nursing, 20(4), pp. 171-7. doi: 10.1016/j. jnn.2013.10.006

Sakalidis, V.S., et al., 2012. Oxygen saturation and suck-swallowbreathe coordination of term infants during breastfeeding and 
feeding from a teat releasing milk only with vacuum. International Journal of Pediatrics, 2012, pp. 1-10. doi: 10.1155/2012/130769

Stevens, E. E., 2007. Preterm infant feeding and cardiorespiratory stability (PhD dissertation). Pennsylvania: University of Pittsburgh.

Thoyre, S. M. \& Carlson, J., 2003a. Occurrence of oxygen desaturation events during preterm infant bottle feeding near discharge. Early Human Development, 72(1), pp. 25-36. doi: 10.1016/ s0378-3782(03)00008-2

Thoyre, S. M. \& Carlson, J. R., 2003b. Preterm infants' behavioural indicators of oxygen decline during bottle feeding. Journal of Advanced Nursing, 43(6), pp. 631-41. doi: 10.1046/j.13652648.2003.02762.x

World Health Organization, 2012. Born too soon: The global action report on preterm birth. Geneva: World Health Organization.

World Health Organization, 2014. World prematurity day. Geneva: World Health Organization.

World Health Organization, 2016. Newborns: Reducing mortality. Geneva: World Health Organization. 